\title{
Article \\ A Decision-Making Approach Based on TOPSIS Method for Ranking Smart Cities in the Context of Urban Energy
}

\author{
Sławomira Hajduk ${ }^{1(\mathbb{D}}$ and Dorota Jelonek ${ }^{2, *}$ (D) \\ 1 Faculty of Engineering Management, Bialystok University of Technology, 45A Wiejska Street, \\ 15-351 Bialystok, Poland; s.hajduk@pb.edu.pl \\ 2 Faculty of Management, Czestochowa University of Technology, 19B Armii Krajowej Street, \\ 42-200 Czestochowa, Poland \\ * Correspondence: dorota.jelonek@pcz.pl
}

Citation: Hajduk, S.; Jelonek, D. A Decision-Making Approach Based on TOPSIS Method for Ranking Smart Cities in the Context of Urban Energy. Energies 2021, 14, 2691. https:// doi.org/10.3390/en14092691

Academic Editor:

Evangelos Pournaras

Received: 14 April 2021

Accepted: 1 May 2021

Published: 7 May 2021

Publisher's Note: MDPI stays neutral with regard to jurisdictional claims in published maps and institutional affiliations.

Copyright: (๑) 2021 by the authors. Licensee MDPI, Basel, Switzerland. This article is an open access article distributed under the terms and conditions of the Creative Commons Attribution (CC BY) license (https:// creativecommons.org/licenses/by/ $4.0 /)$.

\begin{abstract}
This paper presents the use of multi-criteria decision-making (MCDM) for the evaluation of smart cities. During the development of the method, the importance of the decision-making approach in the linear ordering of cities was presented. The method of using the Technique for Order of Preference by Similarity to Ideal Solution (TOPSIS) was proposed for the preparation of ranking. The method was verified by the application in the measurement of energy performance in smart cities. The authors conducted a literature review of research papers related to urban energy and MCDM published in the period from 2010 to 2020. The paper uses data from the World Council on City Data (WCCD). The research conducted allowed for the identification of the most popular MCDM techniques in the field of urban energy such as TOPSIS, AHP and DEA. The TOPSIS technique was used to organize and group the analyzed cities. Porto took the top position, whereas Buenos Aries was the last.
\end{abstract}

Keywords: urban energy; smart city; ISO 37120's indicators; multi-criteria decision making method

\section{Introduction}

Energy generation is the basis of any economic activity, and therefore, the basis for the economic development of cities and countries. It gained importance with the onset of the First Industrial Revolution, and, since then, the energy demand has been growing rapidly. Currently, it is impossible for cities to function normally without a constant energy supply. It is used to power all kinds of devices used, among other things, in industry, communication, agriculture, and many other sectors of the economy. The depletion of energy and materials resources leads to environmental threats and climate change in the world. The EU is committed to achieving the following objectives in the energy policy to 2030 [1]: (1) increasing the share of renewable energy in consumption to $35 \%$ in all sources of energy consumed; (2) improving energy efficiency by 35\%; (3) interconnections covering at least $15 \%$ of the EU electricity systems; (4) an increase of $12 \%$ in the share of renewable energy in transport; (5) a reduction of at least $40 \%$ in greenhouse gas emissions compared to 1990 levels. According to the International Energy Agency [2], electricity consumption has grown from 10,898 TWh in 1990 to 24,739 TWh in 2018 worldwide.

Becoming a smart city is an important task in the transition path and an urban strategy of many cities. They can use different models of building city development strategies e.g., a model of using sentiment analysis to build city strategies and the realization of the related projects [3]. The presented model is a part of a larger work on developing the concept of the Regional Spatial Business Community (RSBC) as an example of a project that will increase the investment attractiveness of cities [4]. Transition processes should take into account the perspectives of involved stakeholders in supporting niche empowering processes necessary for sustainable energy transitions [5]. Koepke, Monstadt and Otsuki [6] argue that debates on urban energy transitions in academia and policy practice need to 
more systematically address the diverse urban development patterns within southern cities, their co-evolution with place-based electricity constellations, and their context-specific challenges and opportunities. Furthermore, as climate change develops, with most of the world population living in urban areas, decarbonization of cities is among the greatest challenges of the coming decades [7].

Local governments constantly introduce innovation to cities by encouraging international enterprises to deploy renewable energy projects and provide green energy services and products to municipalities. Urban leaders need to know how to attract energy sector enterprises. Public managers understand the multi-criteria decision-making problem that energy enterprises face when deciding on the location in a city. Considering how important the energy sector is for sustainable smart cities, this paper focuses on identifying the locations that are critical for energy enterprises when choosing new places to offer the services.

The aim of this paper is to present a ranking of smart cities in the context of energy based on the MCDM method using ISO 37120 indicators. Firstly, the paper identified publications on urban energy and MCDM based on a literature review. Secondly, it attempts to organize the methods and main indicators in the field of urban energy and MCDM. The papers available on the Web of Science, Springer, Scopus, IEEE, and Elsevier databases were reviewed. Inductive thinking was used in the theoretical part whereas the empirical part is based on the TOPSIS technique and entropy method. The paper attempts to answer the following research questions: how can we measure urban energy? Which variables can we use? Which cities have the highest level of urban energy? What is the classification of cities in terms of urban energy?

The procedure for achieving the aims of the study imposed a specific structure of the paper. After the introduction and presentation of the study aims, the Section 2 reviews the literature on the areas of the keywords and the title. The Section 3 describes material and methods, whereas in the fourth, the results are presented and scientifically discussed. The paper ends with a summary and indication of the objectives for development and identification of limitations.

\section{Literature Review}

Contemporary cities are becoming increasingly complex open systems that are always interdependent with their surroundings. The transformations that are observed in the environment imply the necessity to transform cities and develop their smart versions. Mitchell [8] believes that in cities there is a growing web of direct connections to the mechanical and electrical systems of buildings, household appliances, production machinery, process plants, transportation systems, electrical grids, and other energy supply networks, water supply and waste removal networks, systems that provide life safety and security, and management systems for just about every imaginable human activity.

With the absence of a uniform and generally accepted definition of a smart city, different streams in defining this concept can be observed. Initially, it was assumed that a smart city is one in which the information society, with the help of the Internet and information infrastructure, creates a virtual city space [9]. Research in this stream focuses on the use of the most advanced ICT solutions in the creation and development of urban infrastructure in a broad sense [10]. The second stream consists of studies that emphasize the role of human and social capital, education, and environment in the smart city concept. Kourtit and Nijkamp [11] emphasize creativity and knowledge and use the term smart city to refer to cities that aim to improve their socio-economic, environmental, and logistic performance and increase competitiveness.

In conclusion, the most important approaches take into account the multidimensionality and multifaceted nature of the smart city concept, recognition of smart cities as an effective urban development and management model $[12,13]$, the use of models of value delivery from the construction of smart cities [14], recognition of the main drivers for 
increasing the intelligence of cities [15], and the recognition and consistent elimination of barriers to the implementation of the smart city concept [16].

In the urban literature of smart cities, there are some discussions of limitations of smart cities, meaning that not all potential desiring smart cities deserve to be named 'smart'. For example, Nicula et al. [17] deduced that the current poor implementation of smart applications demonstrates Alba Iulia's digital city status not as one of a smart city. The authors argued that some cities, for instance in Central Europe, could not become smart cities because they still have problems with the social inclusion of marginal people. In the near future, the issues of exclusion and contesting racial stigma of Romanies in many European cities must also be addressed [18] and it is necessary to plug stakeholders in by setting up a complex, multi-stakeholder, city-regional urbanity as a way toward real smartness in cities and regions [19]. The long list of challenges that city authorities have to face also includes the fight against corruption and negligence in urban management [20], the challenges of sustainable development, green cities, and, above all, liveable cities [21].

Energy and city are strongly interrelated since cities are a focal point of energy consumption. Modern cities are becoming more and more dependent on the reliability and efficiency of the electrical infrastructure [22]. Tsolakis and Anthopoulos [23] defined a model that reveals the correlations of energy demand and supply with emission producers within a city. The main energy demand sources are the local economic entities from serviceproviding and industry sectors with their buildings, while consumption is measured with a quantitative index of total consumption and consumption per capita. Furthermore, Steemers [24] argues that buildings, transportation, and industry are the main energy users, while energy consumption affects the local microclimate. Energy demand depends on the city's density, and therefore dense cities have lower demand for energy used in transportation and higher for that used in buildings compared to sparse cities. Energy demand in buildings concerns heating and cooling, water heating is needed in houses, and lighting is used in offices. However, Hu and Wang [25] introduced the total-factor energy efficiency model which uses local labor size, capital, farm area, and energy use as the input and local Gross Domestic Product as the output. Additionally, Honma and Hu [26] used the total-factor energy efficiency model and discovered an interrelation between energy efficiency and per-capita income. Cherubini et al. [27] claimed that urban waste management plays a significant role in city energy efficiency. Waste treatment with energy and material recovery ensures important benefits of the reduction in greenhouse gas emissions and significant energy output.

Every city is characterized by a unique energy supply network model [28]. The task of the smart energy service is to find the optimal balance between consumption and production. This system is controlled by sensors for collecting information about the state of the network and the capacity of suppliers. Haarstad and Wathne [29] investigated the links between smart city projects and urban energy sustainability using case studies of three cities: Nottingham, Stavanger, and Stockholm.

Researchers have been studying multidimensionality interactions between cities and energy consumption. Gargiulo and Russo [30] analyzed a comprehensive set of urban factors such as physical features (housing density, house size, house age, house material, green areas), functional features (land use mix, functional specialization), geographical features (degree days, coastal location, topography) and socio-economic features (income, car ownership, household composition, education, ethnicity).

A city's energy efficiency is a complex process that consists in the optimal use of time and energy in a way that does not waste any of them [31]. Efficiency relates to productivity or performance. However, efficiency is also related to sufficiency and, in terms of sustainability, it concerns the optimal energy use with respect for future generations. Through energy conservation policies, municipalities can both save money and reduce negative externalities associated with energy use.

Over the last three decades, a great number of publications in the Web of Science and Elsevier databases (more than 5000) have dealt with urban energy (Figure 1), with a 
significantly increasing trend observed every year. There are more than 600 publications on urban energy from 2018 in the Elsevier database. Furthermore, Trianni et al. [32] analyzed the trends for academic debate and research in the Energy Efficiency journal.

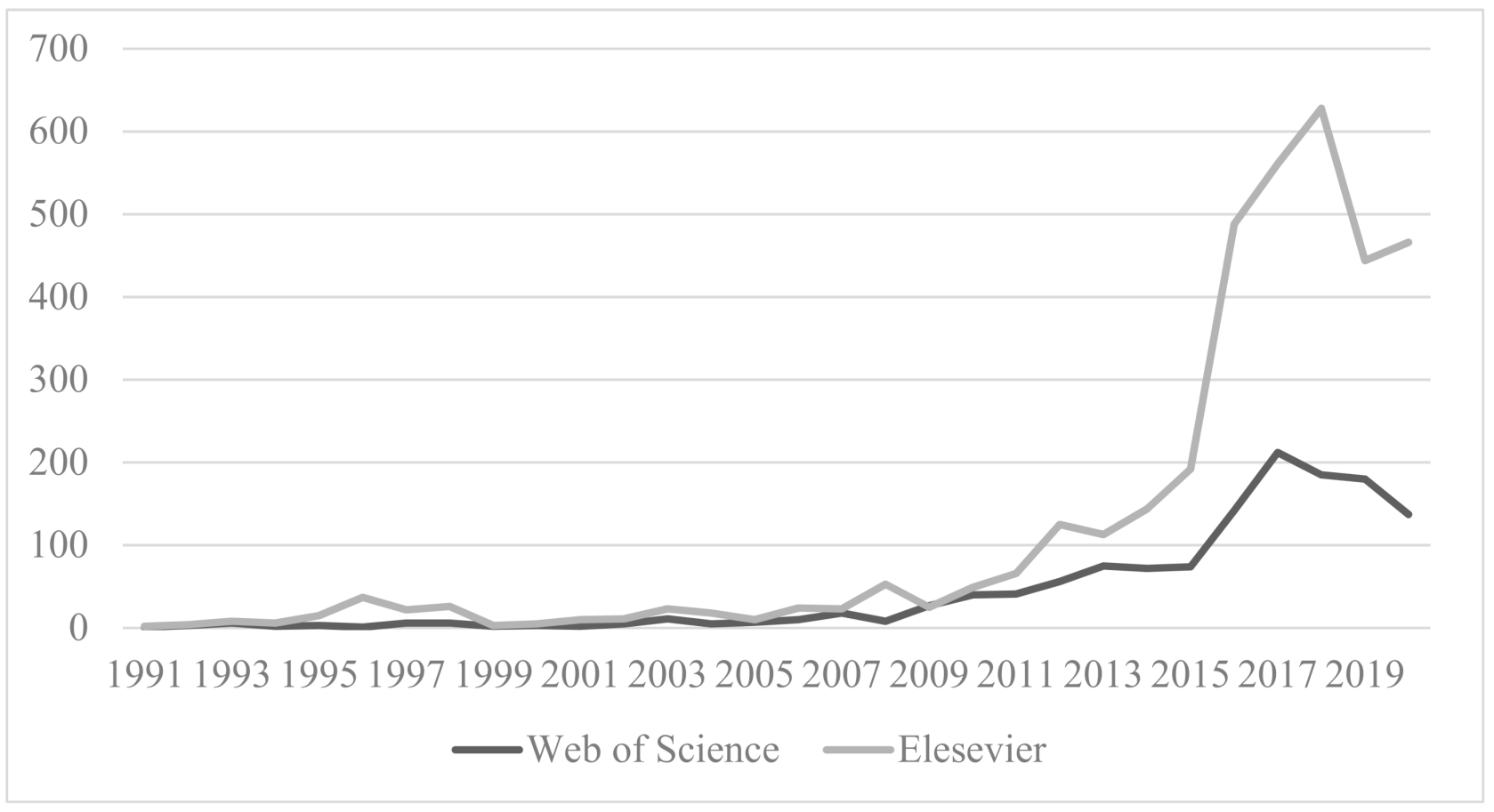

Figure 1. The publications on the topic urban energy, 1991-2020. Source: authors' work.

In the field of operations research, the optimization procedures and approaches were developed to support the business sector in the analysis and solving complex problems, based on multiple and opposite criteria or objectives. Decision-making is a common human practice that requires choosing the best alternative among many. MCDA techniques are considered to be a modern part of operations research, characterized by the multi-objective optimization problem. One of the first publications on MCDM was written by Benjamin Franklin in his work on moral algebra [33]. Since the 1950s, MCDM has been practiced by theoretical and empirical scientists to test the capability of mathematical modeling of the decision-making approach. The MCCM methods are applied in the following sectors: economics, logistics, industrial engineering, environmental science, urban studies, and public policy.

Many researchers have relied on the MCDM or Multi-Criteria Decision Analysis (MCDA). According to Colapinto et al. [34], the top journals referring to MCDA and urban energy based on the number of publications are Journal of Cleaner Production, Sustainability, and Journal of Environmental Management. Energy Policy is worth adding to this list, especially the papers $[35,36]$. Interesting examples of the application of MCDM and MultiCriteria Decision Analysis are presented in the papers $[37,38]$ published in Sustainability.

A total of 276 scientific articles concerning the application of MCDA or MCDM techniques to selected decision-making problems in the field of urban energy from 2010 to 2020 worldwide were analyzed (Figure 2). The authors studied MCDA trends and applications in urban energy. During the analysis, the most frequently used MCDA techniques identified as associated with urban energy were TOPSIS, AHP (Analytic Hierarchy Process), DEA (Data Envelopment Analysis), ELECTRE (Elimination et Choice Translating Reality), PROMETHEE (Preference Ranking Organization Method for Enrichment Evaluation), MACBETH (Measuring Attractiveness by a Categorical Based Evaluation Technique), and VIKOR (Vlsekrzterijumska Optimizacija i Kompromisno Resenje). Furthermore, Mar- 
dani et al. [39] found that most researchers applied fuzzy MCDM, hybrid MCDM, and TOPSIS. Xu et al. [40] summarized the research on DEA in the field of energy efficiency.

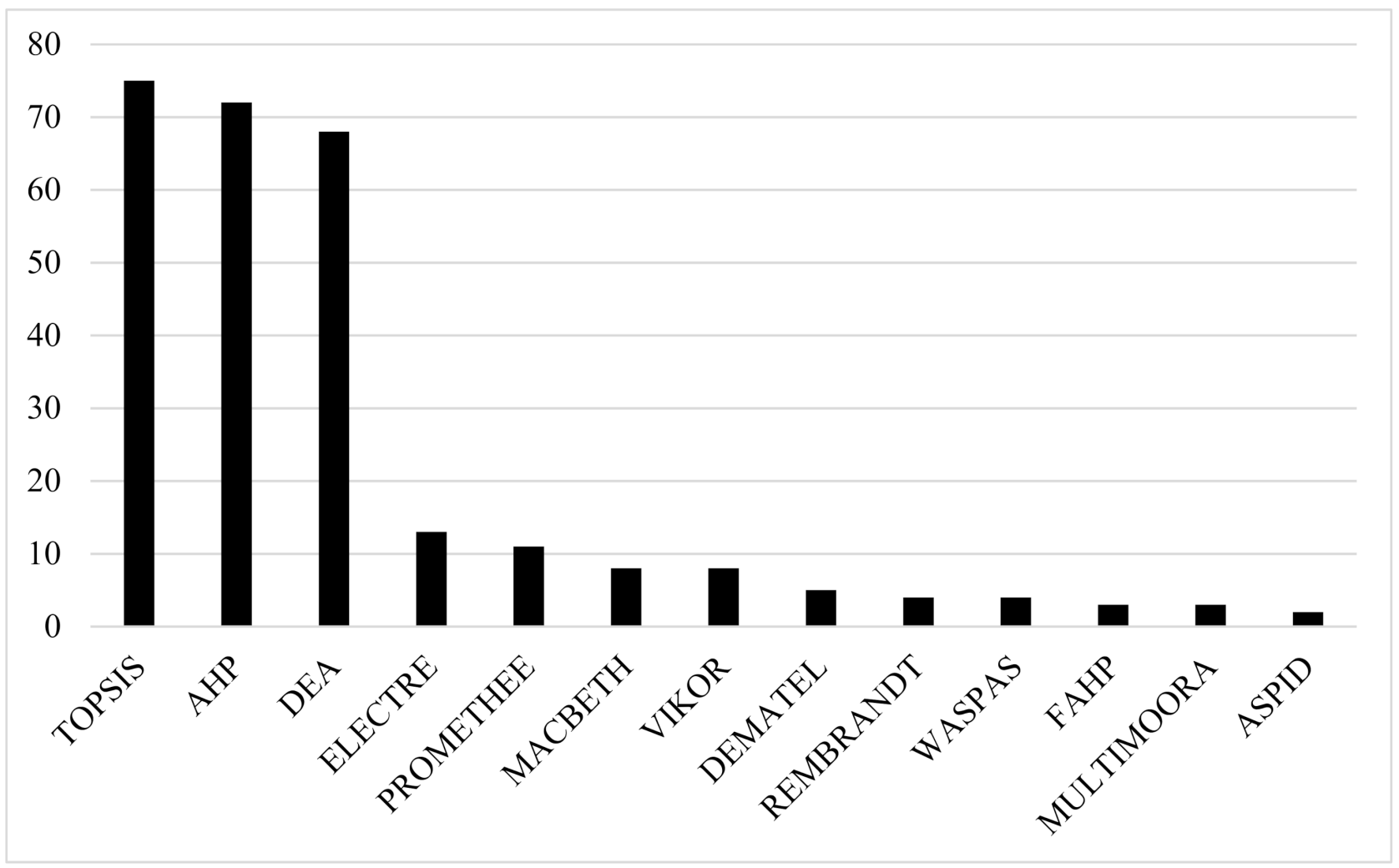

Figure 2. The popularity of MCDA technics in urban energy. Source: authors' work.

The authors conducted a literature review of the publications in the Web of Science and Elsevier databases. Table 1 presents the results of this analysis. The research targeted relevant manuscripts that focused on MCDM techniques in the field of urban energy and were published in 2016-2020. The summary indicates the methods, aims, objects, and main indicators used in the research.

Based on the literature review, the authors identified three areas of urban energy evaluation: (i) urban energy performance, (ii) energy performance of different types, and (iii) energy performance of different objects. The interest in the problem of assessment is great and constant. Most papers focused on the studies related to urban energy performance [60]. The urban energy performance includes urban energy efficiency [49-52,61], urban sustainability performance [56], urban environmental efficiency [58], and low-carbon ecological city evaluation $[42,43,62]$. The energy performance studies of different types include three perspectives: energy well-being performance [47], energy security performance [45], and carbon emission performance [59]. The energy performance studies of different objects refer to the following categories: building energy performance [54], household energy performance, enterprise energy performance [33], industrial energy performance [53], national energy performance [63], and regional energy performance [48]. The energy performance assessment is carried out with the use of evaluation indicators or key factors [64]. The evaluation indicators are divided into input (capital, labor, energy) and output variables (gross domestic product, GDP). The key factors include population, area, urbanization, traveling mode, and climate. 
Table 1. Papers relevant to MCDM and urban energy.

\section{Authors}

Method

To establish a correlation model and

Geng, Zhang, 2020 [41]

TOPSIS

a comprehensive evaluation system between environme
Aims
Objects

cities in Hunan province of China

\section{Main Indicators}

Environment subsystem: resource elements (sown area, water consumption), ecological elements (park green land, green area coverage rate), ecological pressure (sewage discharged, energy consumption), ecological response (gas utilization

rate, sewage treatment rate)

Urbanization subsystem: population (population growth rate, urbanization rate), economic (GDP, investment in

fixed assets, output value of the tertiary industries), spatial (area of paved roads, population density),

social (retail sales of consumer goods, number of vehicles, number of general educations, number of health institutions)

59 major indicators in six categories: science and technology, resource and environment, economy and industry, facilities and functions, critical capital, institution and culture

27 sub-criteria in six criteria:
To design a framework oriented to public managers based on the assessment of criteria and sub-criteria the strategic location decision made by enterprises
Energy sector enterprises of

European cities characteristics of the city's host

country or region, structural factors,

government and its policies,

socioeconomic context, environmenta

conditions, market condition for energy firms 
Table 1. Cont.

Authors

Pang, Fang, 2016 [43]

TOPSIS

Method

Aims

To investigate the dynamic of smart

low-carbon development

Objects

52 indicators from six categories

(science and technology, resource and environment, economy and industry, facilities and functions, critical capital, institution and culture) e.g., number of national key laboratories, energy intensity, GPD city, internet penetration rate, number of R\&D personnel, urbanization level

17 indicators such as: total permanent

residential population, GDP, added value of secondary and tertiary

To measure the centrality together with the factors influencing centrality using data for the population flow

Cities in the Yangtze River Economic Belt 2020 [44]

TOPSIS

To explore the potential links between urban smartness and resilience

87 Chinese cities

Zhu, Li, Feng, 2019 [45] hybrid AHP-TOPSIS

To evaluate the dimensions of smart cities

44 cities around the world

Gokhan, Ceren, 2020 [46]

Analytic Network Process, TOPSIS

To analyze the social, economic and Stanković, Džunić, Džunić, Marinković, 2017 [47]
Combining the AHP and TOPSIS environmental aspects of urban life and to provide the ranking cities according to smart performance
23 Central and Eastern

European cities industries, total fixed assets

investment, total retail sales of consumer goods, actual use of foreign investment, $\mathrm{R} \& \mathrm{D}$ expenditure, tourism income

21 indicators such as: principal arterial, tertiary industry, population natural growth, persons covered of unemployment insurance, green coverage

47 criteria such as: innovation index score, research and development score, entrepreneurship index score

26 qualitative indicators divide into five thematic categories: infrastructure, liveability and housing conditions, environment, employment and finance, governance, urban safety, trust and social cohesion as well as two indictors refers to citizens' perceptions on quality of life in the city (satisfaction with cities and aspects of urban life) 
Table 1. Cont.

Authors

Method

Aims
Carli, Dotoli, Pellegrino, 2018 [48] Sensitive analysis for AHP
To analyze the sustainable
elopment of energy, water and environmental systems, through a set of objective

performance indicators
4 Italian metropolitan areas: Bari, Bitonto, Mola, Molfetta
Objects

\section{Main Indicator}

35 indicators from seven dimensions:

energy consumption and climate (e.g.,

energy consumption per capita)

penetration of energy and $\mathrm{CO}_{2}$ saving

measures; renewable energy potential

and utilization (e.g., renewable energy

in electricity production): water and

environmental quality; $\mathrm{CO}_{2}$ emissions

and industrial profile (e.g., $\mathrm{CO}_{2}$

emissions of buildings); city planning

and social welfare (e.g., GDP per

capita); R\&D, innovation and

sustainability policy (e.g., patents in clean technologies)

Input: capital, area, labor, electricity,

Output: GDP, PM2,5, $\mathrm{SO}_{2}$

Capital (total fixed asset investment) labor (the number of urban employees), energy (annual energy consumption), economic output (gross regional product); urbanization level (urbanization rate), population and area (population density), urban climate (temperature index), travel selection (household car ownership per 100 urban resident households)

Input: total energy consumption Output: heating degree day and
To measure the urban energy efficiency
Five central districts in Shanghai city building area, annual output of 
Table 1. Cont.

\section{Authors}

Method

Aims

Li et al., 2019 [52]

Meta-frontier dynamic DEA

To evaluate the dynamic energy

efficiency of the urban environments

To analyze the changes in industrial production performance and energy

conservation efficiency

To provide a guideline for ranking

different alternatives of building

retrofitting at the building and

Dirutigliano et al., 2018 [54]

PROMOTHEE

$$
\text { district level }
$$

Two projects: District Information

Modelling and Management for

Energy Reduction, Zero Energy

Buildings in Smart Urban District

o analyse and test approaches ir ranking of the evaluation criteria

To assess urban performance in term of eco-efficiency

24 German and 14 French cities

Moutinho et al., 2018 [56]

DEA
To measure the urban metabolic evolution index bove prefecture-level and country-level cities) district (Italy)
656 Chinese cities (including cities

198 buildings in Turin's
Song et al., 2016 [57]
Energy Synthesis, Slacks-Based

Measure DEA Measure DEA

西

\section{Main Indicators}

Input: labor, fixed assets, energy

consumption

$$
\text { Output: GDP }
$$

Carry-over: PM2.5, $\mathrm{SO}_{2}$

Employment number, capital investment of the secondary industry, electricity used in production in the secondary industry

13 economic and socio-environmental criteria: investment cost, replacement cost, maintenance cost, tax detraction, internal comfort, energy bill savings, reliability, built environment,

improvement of internal thermal

comfort, social image and awareness

Economic (investment costs, payback period), environmental (reduction of the $\mathrm{CO}_{2}$ emissions), technical

(reduction of the energy requirement, resilience of the energy systems)

Input: energy consumption, population density, labor productivity, resource productivity, patents per inhabitant Output: $\mathrm{GDP}, \mathrm{CO}_{2}$ emissions

Renewable energy, indigenous renewable energy, locally non-renewable energy, imported energy, exported energy, waste energy 
Table 1. Cont.

Authors Method

Liu et al., 2020 [58]

DEA
Wang et al., 2020 [59]

\author{
on non-expected output \\ Slacks-Based Measure DEA based
}

\section{Aims}

To measure urban green total factor

productivity (GTFP) with a

difference-in-difference

$$
\text { (DID) approach }
$$
To explore the spatiotemporal
evolution of urban carbon

$$
\text { emission performance }
$$

Objects

283 prefecture-level Chinese cities

(96 pilot and 187 non-pilot cities)

Source: authors' elaboration on the basis of [33,41-59].

\section{Main Indicators}

Input variables: capital stock, number

of employees, energy consumption

Output variables: $\mathrm{GDP}, \mathrm{CO}_{2}$ emissions

Control variables: innovation index

Input: fixed-asset investment, inventory

assets, number of employees, energy

consumption, urban

electricity consumption

Expected output: GDP

Non-expected output: urban

$\mathrm{CO}_{2}$ emissions 
ISO standards can be used for assessing urban energy and other dimensions of smart cities [65,66]. For instance, ISO 37122 [67] includes the following indicators: electrical and thermal energy produced from wastewater treatment per capita per year, electrical and thermal energy produced from solid waste treatment per capita per year, the percentage of the city's energy that is produced using decentralized energy production systems, storage capacity of the city's energy grid per capita, the percentage of energy consumption of public street lighting in the total annual municipal energy consumption, the percentage of street lighting that has been refurbished, the percentage of public buildings requiring renovation/refurbishment (by floor area). However, ISO 37123 [68] enumerates only three indicators related to smart urban energy: number of different electricity sources providing at least $5 \%$ of total energy supply capacity, electricity supply capacity as a percentage of peak electricity demand, the percentage of critical facilities served by off-grid energy services. Table 2 presents the general information about ISO standards related to urban energy.

Table 2. Overview of the ISO standards related to urban energy.

\begin{tabular}{|c|c|c|c|c|c|}
\hline & Year & Name of Standard & $\begin{array}{c}\text { Number of } \\
\text { Thematic Groups }\end{array}$ & $\begin{array}{l}\text { Total Number of } \\
\text { Indicators }\end{array}$ & $\begin{array}{c}\text { Number of } \\
\text { Energy Indicators }\end{array}$ \\
\hline ISO 37120 & 2014 & $\begin{array}{l}\text { Sustainable development of } \\
\text { communities-indicators for city } \\
\text { services and quality of life }\end{array}$ & 17 & $46+54 *$ & 7 \\
\hline ISO 37122 & 2019 & $\begin{array}{l}\text { Sustainable cities and } \\
\text { communities-indicators for } \\
\text { smart cities }\end{array}$ & 19 & 76 & 7 \\
\hline ISO 37123 & 2019 & $\begin{array}{l}\text { Sustainable cities and } \\
\text { communities-indicators for } \\
\text { resilient cities }\end{array}$ & 16 & 66 & 3 \\
\hline
\end{tabular}

Legend: * Number of core + supporting indicators. Source: authors' elaboration on the basis of [67-69].

\section{Materials and Methods}

The present study focused on the assessment of urban energy. The research was conducted in three steps: selection, evaluation, and classification (Figure 3). The test procedure consisted of several successive stages: (1) the choice of indicators and objects; (2) the construction of the normalized decision matrix; (3) the calculation of criterion weights based on entropy method; (4) linear ordering using TOPSIS method; (5) clustering of cities; (6) conclusions and recommendations.

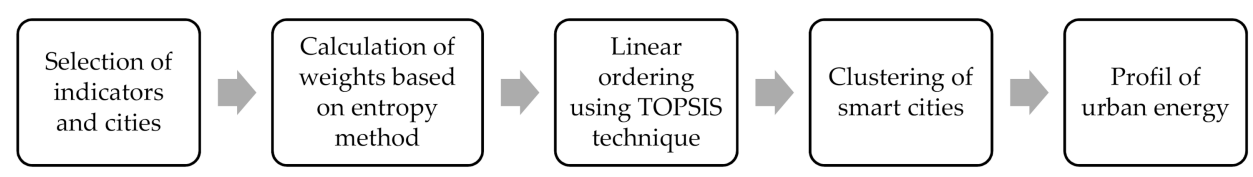

Figure 3. The research design. Source: authors' work.

The study used the TOPSIS technique, which is one of the most commonly used to solve decision-making problems in the field of urban energy. The first method of linear ordering based on the decision theory using patterns and anti-patterns was proposed by Hwang and Yoon in 1981 under the name TOPSIS. The test steps using the classic TOPSIS procedure can be concluded as follows [70]:

Stage 1. The multiple attributes were selected in accordance with substantive and statistical considerations. Then attributes were divided into stimulants (S) and destimulants (D). 
Stage 2. Based on the multiple attributes, the decision matrix $X$ was constructed:

$$
X=\left[x_{i j}\right]=\left[\begin{array}{ccc}
x_{11} & \cdots & x_{1 n} \\
\vdots & \ddots & \vdots \\
x_{m 1} & \cdots & x_{m n}
\end{array}\right]
$$

where: $x_{i j}$ represents the value of the $j$-th attribute $(j=1,2, \ldots, n)$ for the $i$-th objects (cities, $i=1,2, \ldots, m$ ) and $x_{i j} \in \mathrm{R}$.

Stage 3 . The values of attributes were normalized in order to obtain their comparability in accordance with the formula:

$$
r_{i j}=\left\{\begin{array}{cl}
\frac{x_{i j}}{\sum_{j=1}^{n} x_{i j}} & , \text { gdy } j \epsilon \text { stymulant } \\
1-\frac{x_{i j}}{\sum_{j=1}^{n} x_{i j}} & , \text { gdy } j \epsilon \text { destymulant }
\end{array}\right.
$$

Stage 4. The normalized (vector-based) decision matrix was constructed:

$$
R=\left[r_{i j}\right]=\left[\begin{array}{ccc}
r_{11} & \cdots & r_{1 n} \\
\vdots & \ddots & \vdots \\
r_{m 1} & \cdots & r_{m n}
\end{array}\right]
$$

where: $r_{i j}$ means the normalized value of the $j$-th attribute $(j=1,2, \ldots, n)$ for the $i$-th alternatives (cities, $i=1,2, \ldots, m$ ).

Stage 5 . The criterion weight vector $w_{j}$ for the attribute was determined based on the entropy method [71]:

$$
E=\left(e_{1}, e_{2}, \ldots e_{n}\right),
$$

where: $E$ means an entropy vector,

$$
\begin{gathered}
e_{n}=\frac{-1}{\ln m} \sum_{i=1}^{m} z_{i j} \ln z_{i j} \\
z_{i j} \ln z_{i j}=0
\end{gathered}
$$

where: $z_{i j}=0$,

$$
\begin{gathered}
w=\left(w_{1}, w_{2}, \ldots w_{n}\right), \\
\sum_{j=1}^{n} w_{j}=1, w_{j} \epsilon[0,1],
\end{gathered}
$$

where: $w_{j}$ means the criterion weight.

If all the criteria were equally valid, the weights were computed according to the following formula:

$$
\begin{gathered}
w_{j}=\frac{d_{j}}{\sum_{j=1}^{n} d_{j}} \\
d_{j}=1-e_{j}
\end{gathered}
$$

Stage 6. The values of normalized indicators were weighted based on the following formula:

$$
v_{i j}=r_{i j} \cdot w_{j}
$$

Stage 7. Based on the weight of each attribute, the weighted normalized decision matrix $V$ was calculated:

$$
V=\left[v_{i j}\right]=\left[\begin{array}{ccc}
v_{11} & \cdots & v_{1 n} \\
\vdots & \ddots & \vdots \\
v_{m 1} & \cdots & v_{m n}
\end{array}\right]
$$


where: $v_{i j}$ means the weighted and normalized value of the $j$-th attribute $(j=1,2, \ldots, n)$ for the $i$-th alternatives (cities, $i=1,2, \ldots, m$ ).

Stage 8 . The model coordinates of the ideal $\left(A^{+}\right)$and anti-ideal $\left(A^{-}\right)$were established [72]:

$$
\begin{aligned}
& A^{+}=\left(v_{1}^{+}, v_{2}^{+}, \ldots, v_{m}^{+}\right) \\
& A^{-}=\left(v_{1}^{-}, v_{2}^{-}, \ldots, v_{m}^{-}\right)
\end{aligned}
$$

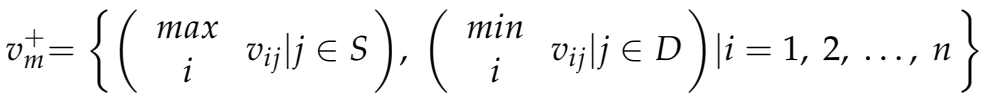

$$
\begin{aligned}
& v_{m}^{-}=\left\{\left(\begin{array}{cc}
\min & v_{i j} \mid j \in S
\end{array}\right),\left(\begin{array}{cc}
\max & \left.\left.v_{i j} \mid j \in D\right) \mid i=1,2, \ldots, n\right\} \\
i &
\end{array}\right.\right.
\end{aligned}
$$

where: $S=\{j=1,2, \ldots, m \mid j$ represent the biggerthe better attribute $\}$;

$D=\{j=1,2, \ldots, m \mid j$ represent the smallerthe better attribute $\}$.

Stage 9 . The positive distance $\left(d_{i}^{+}\right)$and the negative distance $\left(d_{i}^{-}\right)$of each assessed object were calculated as follows:

$$
\begin{aligned}
& d_{i}^{+}=\sqrt{\sum_{j=1}^{m}\left(v_{i j}-v_{j}^{+}\right)^{2}} \\
& d_{i}^{-}=\sqrt{\sum_{j=1}^{m}\left(v_{i j}-v_{j}^{-}\right)^{2}}
\end{aligned}
$$

where: $i=1,2, \ldots, m$.

Stage 10. The values of the relative closeness coefficient $\left(R C_{i}\right)$ of each object were calculated:

$$
R C_{i}=\frac{d_{i}^{-}}{d_{i}^{+}+d_{i}^{-}}
$$

where: $0 \leq R C_{i} \leq 1, i=1,2, \ldots, m$.

Stage 11. The modification of the relative closeness coefficient $\left(R C_{i}{ }^{\prime}\right)$ in the classic TOPSIS procedure was applied to simplify the smart cities levels according to the following formula:

$$
R C_{i}^{\prime}=\frac{R C_{i}}{\sum_{i=1}^{m} R C_{i}},(i=1,2, \ldots, m)
$$

Stage 12. The ranking of smart cities was prepared.

Stage 13. The classification was determined based on the relative closeness coefficient $\left(R C_{i}\right)$ as well as arithmetic mean $\left(\overline{R C_{i}}\right)$ and standard deviation $\left(S_{R C i}\right)$ with typological classes specified through the creation of four separate groups of similar objects:

Class I: if the relative closeness coefficient is $R C_{i} \geq \overline{R C_{i}}+S_{R C_{i}}$;

Class II: if the relative closeness coefficient is $\overline{R C_{i}} \leq R C_{i}<\overline{R C_{i}}+S_{R C i}$;

Class III: if the relative closeness coefficient is $\overline{R C_{i}}-S_{R C_{i}} \leq R C_{i}<\overline{R C_{i}}$;

Class IV: if the relative closeness coefficient is $R C_{i}<\overline{R C_{i}}-S_{R C i}$.

In the context of urban energy, the ranking of smart cities is complex and multifaced [73]. Firstly, cities consist of many interrelated systems, which impact each other. Secondly, various stakeholders in cities may have conflicting ideas.

Empirical materials within this study were based on currently available statistical data listed by the WCCD (www.open.dataforcities.org) between 2014 and 2017. Indicators were selected from ISO 37120:2014 standard, namely [74]:

X1 - total residential electrical energy use per capita;

X2-a share of city population with authorized electrical service;

X3 - energy (electricity) consumption of public buildings per year; 
X4-a share of the city's total energy consumption energy derived from renewable sources;

X5-total electrical energy use per capita;

$\mathrm{X} 6$ - average number of electrical interruptions;

$\mathrm{X} 7$-average length of electrical interruptions.

There are four core $(X 1, X 2, X 3, X 4)$ and three supporting indicators $(X 5, X 6, X 7)$.

The following analysis includes cities from 6 world regions (without Africa). Table 3 presents the general overview of the analyzed cities. The urban profile involves the features such as a country, a year of ISO 37120 certification, a city population, a city land area, a population density, and a city product.

Table 3. The selected cities profile.

\begin{tabular}{|c|c|c|c|c|c|c|}
\hline Cities & Country & $\begin{array}{c}\text { Certification } \\
\text { Year }\end{array}$ & Population & $\begin{array}{l}\text { City Land } \\
\text { Area }\left[\mathrm{km}^{2}\right]\end{array}$ & $\begin{array}{c}\text { Population } \\
\text { Density }\end{array}$ & $\begin{array}{l}\text { City Product per } \\
\text { Capita [USD] }\end{array}$ \\
\hline Amsterdam & Netherlands & 2014 & 834,713 & 164.66 & 5065.00 & $71,627.00$ \\
\hline Hague & Netherlands & 2017 & 519,988 & 98.13 & 5298.97 & $45,933.67$ \\
\hline Zwolle & Netherlands & 2017 & 124,896 & 119.30 & 1046.00 & $42,988.80$ \\
\hline Oslo & Norway & 2016 & 658,390 & 426.38 & 1544.14 & $95,628.00$ \\
\hline Zagreb & Croatia & 2016 & 790,017 & 641.32 & 1232.48 & $20,181.20$ \\
\hline Valencia & Spain & 2015 & 787,266 & 137.48 & 5849.19 & $24,288.33$ \\
\hline Porto & Portugal & 2016 & 214,329 & 41.42 & 5180.50 & 863.75 \\
\hline Sintra & Portugal & 2017 & 382,521 & 319.23 & 1198.30 & $20,801.29$ \\
\hline Boston & USA & 2014 & 672,840 & 125.00 & 5383.00 & $177,079.00$ \\
\hline Doral & USA & 2016 & 51,382 & 40.06 & 1281.02 & $76,066.18$ \\
\hline San Diego & USA & 2016 & $1,381,083$ & 842.23 & 1639.79 & $62,295.00$ \\
\hline $\begin{array}{l}\text { Saint-Augustin-de- } \\
\text { Desmaures }\end{array}$ & Canada & 2016 & 19,369 & 85.84 & 225.64 & $119,889.10$ \\
\hline Toronto & Canada & 2015 & $2,808,503$ & 634.00 & 4430.00 & $50,325.00$ \\
\hline Piedras Negras & Mexico & 2018 & 163,595 & 70.87 & 2308.38 & 8829.54 \\
\hline Torreon & Mexico & 2016 & 679,288 & 305.23 & 2225.50 & $11,352.00$ \\
\hline Buenos Aires & Argentina & 2014 & $2,890,151$ & 203.00 & $14,450.80$ & $27,720.00$ \\
\hline Brisbane & Australia & 2016 & $1,184,215$ & 1338.10 & 882.00 & $48,416.33$ \\
\hline Melbourne & Australia & 2014 & 122,207 & 37.70 & 3088.78 & 587.14 \\
\hline Tbilisi & Georgia & 2017 & $1,113,000$ & 502.00 & 2217.13 & $55,343.19$ \\
\hline Amman & Jordan & 2014 & $2,584,600$ & 680.00 & 3800.88 & 2705.81 \\
\hline ArRiyadh & $\begin{array}{l}\text { Saudi } \\
\text { Arabia }\end{array}$ & 2016 & $6,506,700$ & 3115.00 & 2088.00 & $22,213.00$ \\
\hline
\end{tabular}

Source: authors' elaboration based on [75].

The city with the largest land area and population is ArRiyadh $\left(6,506,700 ; 3115 \mathrm{~km}^{2}\right)$, but Buenos Aires has the highest population density $(14,450.8)$. The highest city product per capita was reported in Boston (177,079 USD), while the lowest was Melbourne (587.14 USD).

The TOPSIS technique is based on 21 alternatives analysed with respect to seven criteria. The distances from the positive ideal and negative ideal solutions allowing for the formation of a linear ordering are determined. Table 4 shows the characteristics of TOPSIS in terms of alternatives and criteria. 
Table 4. Steps of the TOPSIS method.

\begin{tabular}{|c|c|c|c|}
\hline & Input & Process & Output \\
\hline Alternatives & $\begin{array}{l}\text { AM HG ZW OS ZA VA } \\
\text { PO SI BO DO SD SA } \\
\text { TO PN TR BA BR ME } \\
\text { TB AN AR }\end{array}$ & \multirow[t]{2}{*}{$\begin{array}{l}\text { Calculation of } \\
\text { TOPSIS technique }\end{array}$} & \multirow[t]{2}{*}{$\begin{array}{c}\text { Results, ranking and } \\
\text { clustering }\end{array}$} \\
\hline Criteria & $\begin{array}{lllll}X_{1} & X_{2} & X_{3} & X_{4} & X_{5} \\
X_{6} & X_{7} & & & \end{array}$ & & \\
\hline
\end{tabular}

Source: authors' elaboration.

\section{Results and Discussion}

The research began with computing the basic statistics for urban energy indicators by measuring the position (arithmetic mean) and variability (standard deviation, variation coefficient). The share of the city's total consumption of energy derived from renewable sources $(161.3 \%)$ is the most varied indicator, whereas the percentage of the city's population with authorized electrical services $(7.5 \%)$ provides the least information. Table 5 presents the general statistics of each indicator.

Table 5. The basic statistics of urban energy indicators.

\begin{tabular}{|c|c|c|c|c|c|c|c|}
\hline & Units & Character & $\bar{x}$ & $S_{D}$ & $V$ & Max Value, City & Min Value, City \\
\hline $\mathrm{X} 1$ & kWh/Year/capita & $\mathrm{D}$ & 2558.8 & 2331.8 & 91.1 & 9201.5 SA & 127.2 AN \\
\hline $\mathrm{X} 2$ & $\%$ & S & 97.9 & 7.3 & 7.5 & $100.0 \quad \mathrm{PO}$ & $98.62 \quad$ BA \\
\hline X3 & $\mathrm{kWh} / \mathrm{m}^{2} /$ year & $\mathrm{D}$ & 149.0 & 160.5 & 107.8 & $615.1 \quad$ TO & $5.1 \quad \mathrm{TR}$ \\
\hline $\mathrm{X} 4$ & $\%$ & $S$ & 18.2 & 29.4 & 161.3 & 99.0 OS & $0.0 \quad \mathrm{BA}$ \\
\hline X5 & kWh/Year/capita & $\mathrm{D}$ & 9412.3 & 7487.3 & 79.5 & $28,375 \quad \mathrm{PN}$ & 1200.5 AN \\
\hline $\mathrm{X} 6$ & customer/year & $\mathrm{D}$ & 0.86 & 1.21 & 140.9 & $6.0 \quad \mathrm{BA}$ & $0.0 \quad \mathrm{PO}$ \\
\hline $\mathrm{X} 7$ & hours & $\mathrm{D}$ & 1.5 & 2.3 & 152.1 & $13.5 \quad \mathrm{BA}$ & $0.0 \mathrm{SI}$ \\
\hline
\end{tabular}

Legend: $\bar{x}$ - the arithmetic mean, SX—the standard deviation, V—-the variation coefficient. S—stimulant, S-destimulant. Source: elaborated by the authors based on [75]

In the next step, a decision matrix $(X)$ was developed. Then, the normalized decision matrix $(R)$ was developed based on a normalized vector $(r)$. Results of calculated the normalized decision matrix are summarized in Appendix A.

Based on the entropy method, the entropy vector $(e)$ and the criterion weight vector $(w)$ were determined. Table 6 shows the weights of the evaluation criteria. The most important criterion was $X_{7}(w=0.18550)$ whereas the least important was $X_{2}(w=0.00000)$.

Table 6. Weights of the evaluation criteria.

\begin{tabular}{cccccccc}
\hline & $\mathbf{X 1}$ & $\mathbf{X 2}$ & $\mathbf{X 3}$ & $\mathbf{X 4}$ & $\mathbf{X 5}$ & $\mathbf{X 6}$ & $\mathbf{X 7}$ \\
\hline$e$ & 0.31331 & 1.00000 & 0.31159 & 0.68221 & 0.31475 & 0.29990 & 0.29896 \\
\hline$d$ & 0.68669 & 0.00000 & 0.68841 & 0.31779 & 0.68525 & 0.70010 & 0.70104 \\
\hline$w$ & 0.18170 & 0.00000 & 0.18215 & 0.08409 & 0.18132 & 0.18525 & 0.18550 \\
\hline
\end{tabular}

Weight factors $(w)$ were determined and the weighted normalized decision matrix $(V)$ was developed. Appendix B presents the weighted normalized decision matrix.

Results of the calculated relative closeness coefficient $(R C)$ and the ranking of smart cities compared to the basic level of urban energy are summarized in Table 7. Likewise, the positive distance $\left(d^{+}\right)$and the negative distance $\left(d^{+}\right)$were presented in this table. 
The values of the relative closeness coefficient range from 0.29794 to 0.82071 , while the modification of the relative closeness coefficient $(R C /)$-from 0.0197434 and 0.0543855 .

Table 7. The ranking of smart cities.

\begin{tabular}{|c|c|c|c|c|c|}
\hline Cities & $d^{+}$ & $d^{-}$ & $R C$ & $R C^{\prime}$ & Rank \\
\hline $\mathrm{AM}$ & 0.02167 & 0.09234 & 0.80993 & 0.0536712 & 2 \\
\hline $\mathrm{HG}$ & 0.02430 & 0.09489 & 0.79611 & 0.0527552 & 4 \\
\hline $\mathrm{ZW}$ & 0.02415 & 0.09157 & 0.79131 & 0.0524375 & 7 \\
\hline OS & 0.02564 & 0.08945 & 0.77719 & 0.0515017 & 10 \\
\hline $\mathrm{ZA}$ & 0.03513 & 0.07396 & 0.67793 & 0.044924 & 15 \\
\hline VA & 0.02559 & 0.08855 & 0.77578 & 0.0514085 & 11 \\
\hline $\mathrm{PO}$ & 0.02054 & 0.09401 & 0.82071 & 0.0543855 & 1 \\
\hline SI & 0.02501 & 0.09608 & 0.79350 & 0.0525823 & 6 \\
\hline $\mathrm{BO}$ & 0.02370 & 0.09198 & 0.79513 & 0.0526905 & 5 \\
\hline $\mathrm{DO}$ & 0.04258 & 0.08065 & 0.65447 & 0.0433695 & 18 \\
\hline SD & 0.02590 & 0.08556 & 0.76763 & 0.0508684 & 12 \\
\hline SA & 0.04987 & 0.06461 & 0.56441 & 0.0374019 & 20 \\
\hline $\mathrm{TO}$ & 0.04491 & 0.07741 & 0.63285 & 0.0419366 & 19 \\
\hline $\mathrm{PN}$ & 0.04369 & 0.09154 & 0.67690 & 0.0448562 & 16 \\
\hline TR & 0.02507 & 0.09148 & 0.78488 & 0.0520116 & 9 \\
\hline $\mathrm{BA}$ & 0.09026 & 0.03831 & 0.29794 & 0.0197434 & 21 \\
\hline $\mathrm{BR}$ & 0.02489 & 0.09336 & 0.78952 & 0.0523191 & 8 \\
\hline ME & 0.04028 & 0.08002 & 0.66520 & 0.0440807 & 17 \\
\hline TB & 0.02167 & 0.09140 & 0.80835 & 0.0535666 & 3 \\
\hline AN & 0.03162 & 0.08374 & 0.72589 & 0.0481026 & 13 \\
\hline $\mathrm{AR}$ & 0.03568 & 0.07755 & 0.68491 & 0.0453869 & 14 \\
\hline
\end{tabular}

Source: authors' work.

The relative closeness coefficient $(R C)$ was defined for each smart city. As a result, Porto (PO) was found to be the most desirable city among these alternatives, overtaking its nearest competitor, Amsterdam (AM). Saint-Augustin-de-Desmaures (SA) ranked twelve, leaving Buenos Aires (BA) last. Figure 4 presents a visualization and a summary of the relative closeness coefficient.

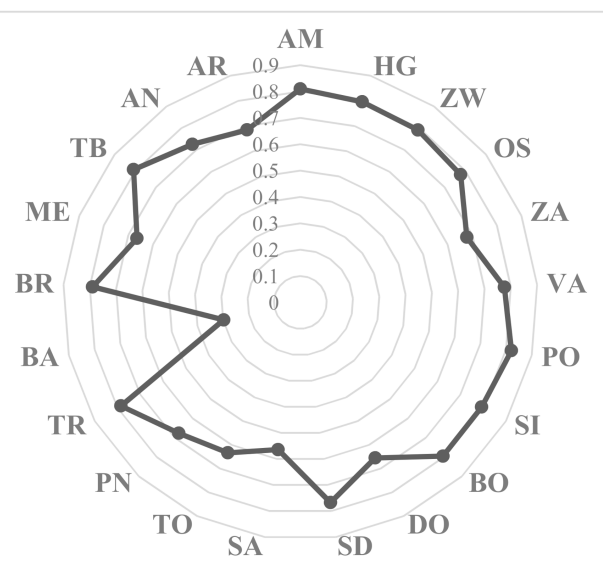

Figure 4. The visualization of relative closeness coefficient. Source: authors' work. 
Using the values of the relative closeness coefficient, a four-level classification of smart cities can be derived based on the assessment of urban energy. Table 8 presents the classification of smart cities by their level of urban energy. From the table, it can be seen that none of the sample smart cities reached the 'excellent' status with regard to its urban energy. The majority of smart cities (thirteen) were with the 'good' status and $R C$ was above 0.7186. ArRiyadh (AR), Zagreb (ZA), Piedras Negras (PN), Melbourne (ME), Doral (DO), and Toronto (TO) belong to group III, with $R C$ between 0.59865 and 0.7186 . Two cities (SA, BA) were with the 'low' status and $R C$ below 0.59865 .

Table 8. Classification of smart cities in terms of urban energy level.

\begin{tabular}{cccc}
\hline Level & Status & Ranges & Cities \\
\hline I & Excellent & $R C>0.83854$ & - \\
\hline II & Good & $0.7186<R C<0.83854$ & $\begin{array}{c}\text { PO, AM, TB, HG, BO, SI, ZW, } \\
\text { BR, TR, OS, VA, SD, AN }\end{array}$ \\
\hline III & Medium & $0.59865<R C<0.7186$ & AR, ZA, PN, ME, DO, TO \\
\hline IV & Low & $R C<0.59865$ & SA, BA \\
\hline
\end{tabular}

Source: authors' work.

In conclusion, the overall assessment of smart cities is sufficient, but they performed poorly in promoting the concepts of a low-carbon city and sustainable development. Furthermore, the percentage of the city's total consumption of the energy derived from renewable sources $(\mathrm{X} 4)$ is low among the criteria analyzed and the weight is only $8.4 \%$. Additionally, the average number (X6) and time of electrical interruptions (X7) are extremely important criteria ( $18.52 \%$ and $18.55 \%$, respectively).

The relationship between city product per capita and closeness coefficient was analyzed. Most cities with a high city product belong to cluster 2. The assessment carried out identified three outlier cities, which are Boston, Saint-Augustin-de-Desmaures, and Buenos Aires. The trend line shows that a $\$ 1$ increase in city product causes an increase in closeness coefficient by $2 \cdot 10^{-7}$. Figure 5 presents a dependence of city product and relative closeness coefficient.

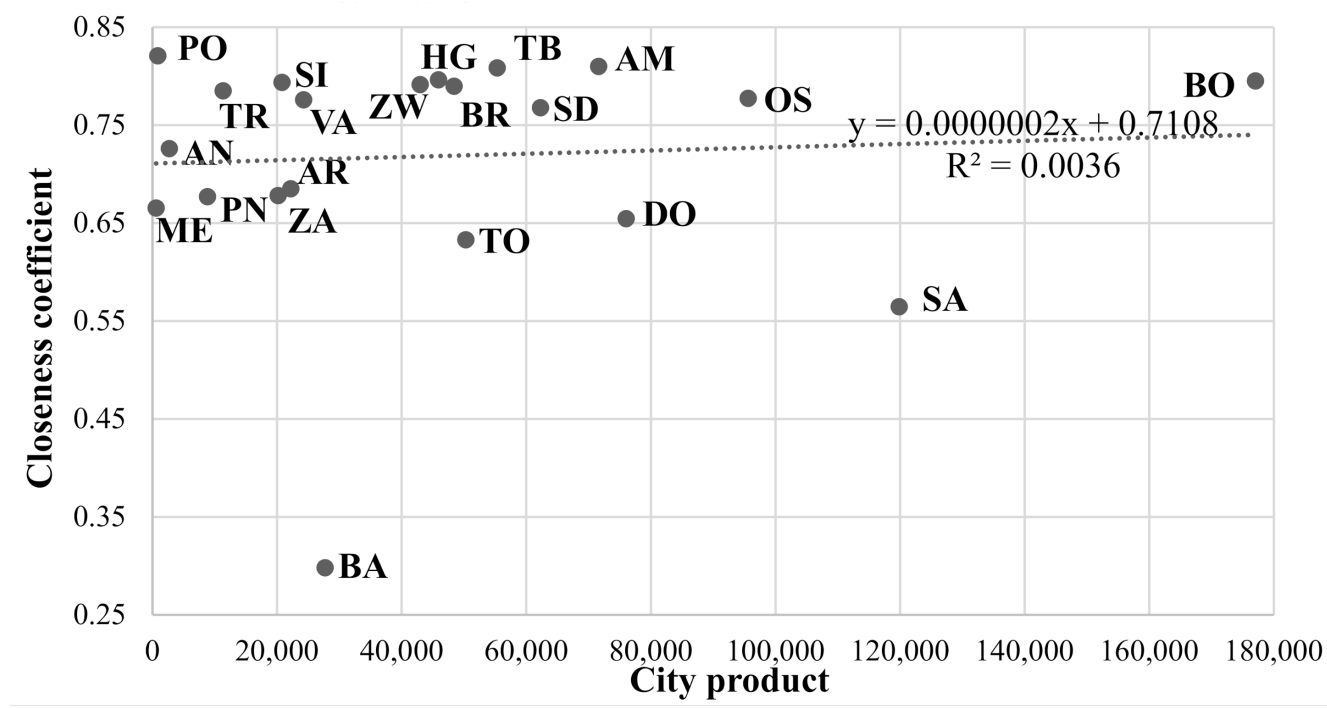

Figure 5. The dependence of city product and relative closeness coefficient. Source: authors' work.

Porto is a city where power outages do not occur and it ranked first in the ranking of cities. A similar situation is observed in Hague and Sintra, with the 4th and 5th positions in the ranking of cities, respectively. In contrast, the largest percentage of renewable energy sources was found in Oslo and Saint-Augustin-de-Desmaures. Buenos Aires, Piedras 
Negras, and ArRiyadh ranked 21st, 16th, and 14th among cities, respectively. The highest electricity consumption per capita was reported in Saint-Augustin-de-Desmaures and Piedras Negras.

Porro et al. note that financial facilitation, support for public-private partnerships, the level of transparency, and the degree of bureaucracy are important criteria when making decisions on the location of energy companies [33]. Wang et al. state that urbanization rate, temperature index, and having a car in a household are positively related to urban energy efficiency [50]. Dirutigliano et al. believe that the construction sector plays a fundamental role in urban energy consumption [54]. Furthermore, Wang et al. suggest that energy savings can be achieved by improving the efficiency of carbon dioxide emissions [59]. The research indicates that the time of power outages has the greatest influence on the value of the closeness coefficient.

\section{Conclusions}

The smart city rankings exhaustively analyze the areas of smart cities, such as economy, mobility, environment, quality of life, social capital, and management. Unfortunately, the energy aspects of the modern city are insufficiently considered. The concept of a smart city should put more emphasis on energy, which, if implemented in a sustainable manner, is likely to contribute to the reduction of city maintenance costs, economic growth, and to fulfill the obligations imposed on the member states by the European Union regarding pollutant emissions and respect for the natural environment. The identification of smart cities in terms of energy should be based on energy consumption per inhabitant, urban energy networks, energy-efficient and interactive buildings, and urban power technologies. An energy-efficient smart city should stand out in the following areas: renewable energy resources, electrical network, heating network, cogeneration, thermal efficiency improvement in facilities, interactive buildings, and sustainability of the energy system.

Based on theoretical and empirical studies, it can be concluded that:

- Urban energy is an important research direction, as confirmed by the growing number of publications.

- MCDM techniques are one of the important tools in solving decision-making problems in the field of urban energy, especially energy efficiency, sustainability performance, environmental efficiency, and low-carbon ecological city evaluation.

- TOPSIS, AHP, and DEA are the most popular MCDM techniques in the field of urban energy.

- A ranking of smart cities in terms of urban energy was obtained based on the multicriteria analysis conducted using the TOPSIS technique. Porto was found to be the best location for energy enterprises and projects. Bueno Aires was ranked last.

The proposed research procedure can be used to analyse and evaluate cities in a country, but also to select alternatives in the context of other urban characteristics.

The paper contributes to the existing literature by complementing the location theory using TOPSIS technique for urban energy investment decisions. Furthermore, it provides city managers with information on variables that are relevant to energy companies looking for new locations to operate.

Future research objectives using the TOPSIS procedure will involve other algorithms of normalization and criteria weighting. It is also planned to extend the analysis to the other research objects (European cities, Polish cities) using TOPSIS. The authors intend to develop rankings based on other popular MDCM techniques, e.g., DEA, AHP.

This study has also some limitations. The paper uses available and measurable indicators while omitting those that are difficult to obtain and evaluate. However, the analysis should be multidimensional and comprehensive. Therefore, more indicators should be considered and selected in future research. Furthermore, TOPSIS is a sensitive technique because of its method of normalization and weighing the criteria. 
Author Contributions: Conceptualization S.H. and D.J.; methodology, S.H. and D.J.; writingoriginal draft preparation, S.H. and D.J. (Introduction-D.J., Materials and Methods and Results-D.J. and S.H., Discussion and Conclusions-S.H.). All authors have read and agreed to the published version of the manuscript.

Funding: This study was realized during scientific project WZ/WIZ/-INZ/2/2019 supported by Polish Ministry of Education and Science.

Institutional Review Board Statement: Not applicable.

Informed Consent Statement: Not applicable.

Data Availability Statement: Not applicable.

Acknowledgments: The authors thanks everyone who provided constructive advice that helped to improve this paper.

Conflicts of Interest: The authors have declared that no competing interest exist.

\section{Abbreviations}

$\begin{array}{ll}\text { AM } & \text { Amsterdam } \\ \text { HG } & \text { Hague } \\ \text { ZW } & \text { Zwolle } \\ \text { OS } & \text { Oslo } \\ \text { ZA } & \text { Zagreb } \\ \text { VA } & \text { Valencia } \\ \text { PO } & \text { Porto } \\ \text { SI } & \text { Sintra } \\ \text { BO } & \text { Boston } \\ \text { DO } & \text { Doral } \\ \text { SD } & \text { San Diego } \\ \text { SA } & \text { Saint-Augustin-de-Desmaures } \\ \text { TO } & \text { Toronto } \\ \text { PN } & \text { Piedras Negras } \\ \text { TR } & \text { Torreon } \\ \text { BA } & \text { Bueno Aires } \\ \text { BR } & \text { Brisbane } \\ \text { ME } & \text { Melbourne } \\ \text { TB } & \text { Tbilisi } \\ \text { AN } & \text { Amman } \\ \text { AR } & \text { ArRiyadh }\end{array}$

\section{Appendix A}

Table A1. Normalized decision matrix.

\begin{tabular}{cccccccc}
\hline & $\mathbf{X 1}$ & $\mathbf{X 2}$ & $\mathbf{X 3}$ & $\mathbf{X} \mathbf{1}$ & $\mathbf{X 5}$ & $\mathbf{X 6}$ & $\mathbf{X 7}$ \\
\hline AM & 0.97924 & 0.04765 & 0.97696 & 0.04217 & 0.97196 & 0.98619 & 0.98609 \\
\hline HG & 0.98204 & 0.04770 & 0.97348 & 0.00386 & 0.98213 & 1.00000 & 0.99292 \\
\hline ZW & 0.97935 & 0.04770 & 0.96794 & 0.01740 & 0.97523 & 0.99841 & 0.97218 \\
\hline OS & 0.89166 & 0.04770 & 0.93839 & 0.28425 & 0.93069 & 0.97876 & 0.97547 \\
\hline ZA & 0.97976 & 0.04714 & 0.97618 & 0.00238 & 0.98308 & 0.91184 & 0.89555 \\
\hline VA & 0.97427 & 0.04770 & 0.98365 & 0.01375 & 0.98349 & 0.94636 & 0.98280 \\
\hline PO & 0.96674 & 0.04770 & 0.99328 & 0.06033 & 0.97166 & 1.00000 & 0.97673 \\
\hline SI & 0.96749 & 0.04770 & 0.99480 & 0.00777 & 0.95324 & 1.00000 & 1.00000 \\
\hline BO & 0.96461 & 0.04770 & 0.96187 & 0.04351 & 0.95028 & 0.98354 & 1.00000 \\
\hline
\end{tabular}


Table A1. Cont.

\begin{tabular}{cccccccc}
\hline & $\mathbf{X 1}$ & $\mathbf{X 2}$ & $\mathbf{X 3}$ & $\mathbf{X} \mathbf{4}$ & $\mathbf{X 5}$ & $\mathbf{X 6}$ & $\mathbf{X 7}$ \\
\hline DO & 0.89697 & 0.04770 & 0.88836 & 0.00116 & 0.89188 & 0.92990 & 0.99975 \\
\hline SD & 0.96700 & 0.04770 & 0.94478 & 0.03278 & 0.96663 & 0.96654 & 0.96813 \\
\hline SA & 0.83479 & 0.04770 & 0.92006 & 0.28280 & 0.90912 & 0.84387 & 0.90137 \\
\hline TO & 0.96687 & 0.04770 & 0.78795 & 0.09050 & 0.95408 & 0.92618 & 0.98002 \\
\hline PN & 0.85841 & 0.04770 & 0.95436 & 0.00000 & 0.85511 & 0.99947 & 0.99899 \\
\hline TR & 0.99083 & 0.04770 & 0.99824 & 0.00096 & 0.98553 & 0.96283 & 0.98306 \\
\hline BA & 0.97262 & 0.04704 & 0.95852 & 0.00000 & 0.97867 & 0.68136 & 0.65857 \\
\hline BR & 0.96236 & 0.04770 & 0.95605 & 0.02349 & 0.95984 & 0.99841 & 0.99798 \\
\hline ME & 0.96892 & 0.04770 & 0.87563 & 0.03582 & 0.86170 & 0.98513 & 0.95245 \\
\hline TB & 0.98423 & 0.04770 & 0.99328 & 0.05604 & 0.98794 & 0.99947 & 0.94790 \\
\hline AN & 0.99771 & 0.04736 & 0.98065 & 0.00104 & 0.99387 & 0.99203 & 0.88948 \\
\hline AR & 0.91411 & 0.04765 & 0.97557 & 0.00000 & 0.95388 & 0.90972 & 0.94057 \\
\hline Soure: authors ${ }^{\prime}$ work. & & & & &
\end{tabular}

Source: authors' work.

\section{Appendix B}

Table A2. Weighted normalized decision matrix.

\begin{tabular}{cccccccc}
\hline & $\mathbf{X 1}$ & $\mathbf{X 2}$ & $\mathbf{X 3}$ & $\mathbf{X 4}$ & $\mathbf{X 5}$ & $\mathbf{X 6}$ & $\mathbf{X 7}$ \\
\hline AM & 0.17793 & 0.00000 & 0.17796 & 0.00355 & 0.17623 & 0.18269 & 0.18292 \\
\hline HG & 0.17844 & 0.00000 & 0.17732 & 0.00032 & 0.17808 & 0.18525 & 0.18418 \\
\hline ZW & 0.17795 & 0.00000 & 0.17631 & 0.00146 & 0.17683 & 0.18495 & 0.18034 \\
\hline OS & 0.16201 & 0.00000 & 0.17093 & 0.02390 & 0.16875 & 0.18131 & 0.18095 \\
\hline ZA & 0.17802 & 0.00000 & 0.17781 & 0.00020 & 0.17825 & 0.16892 & 0.16612 \\
\hline VA & 0.17702 & 0.00000 & 0.17918 & 0.00116 & 0.17833 & 0.17531 & 0.18231 \\
\hline PO & 0.17566 & 0.00000 & 0.18093 & 0.00507 & 0.17618 & 0.18525 & 0.18118 \\
\hline SI & 0.17579 & 0.00000 & 0.18121 & 0.00065 & 0.17284 & 0.18525 & 0.18550 \\
\hline BO & 0.17527 & 0.00000 & 0.17521 & 0.00366 & 0.17230 & 0.18220 & 0.18550 \\
\hline DO & 0.16298 & 0.00000 & 0.16182 & 0.00010 & 0.16171 & 0.17226 & 0.18545 \\
\hline SD & 0.17570 & 0.00000 & 0.17210 & 0.00276 & 0.17527 & 0.17905 & 0.17959 \\
\hline SA & 0.15168 & 0.00000 & 0.16759 & 0.02378 & 0.16484 & 0.15632 & 0.16720 \\
\hline TO & 0.17568 & 0.00000 & 0.14353 & 0.00761 & 0.17299 & 0.17157 & 0.18179 \\
\hline PN & 0.15597 & 0.00000 & 0.17384 & 0.00000 & 0.15505 & 0.18515 & 0.18531 \\
\hline TR & 0.18003 & 0.00000 & 0.18183 & 0.00008 & 0.17869 & 0.17836 & 0.18235 \\
\hline BA & 0.17672 & 0.00000 & 0.17460 & 0.00000 & 0.17745 & 0.12622 & 0.12216 \\
\hline BR & 0.17486 & 0.00000 & 0.17415 & 0.00198 & 0.17404 & 0.18495 & 0.18512 \\
\hline ME & 0.17605 & 0.00000 & 0.15950 & 0.00301 & 0.15624 & 0.18249 & 0.17668 \\
\hline TB & 0.17883 & 0.00000 & 0.18093 & 0.00471 & 0.17913 & 0.18515 & 0.17583 \\
\hline AN & 0.18128 & 0.00000 & 0.17863 & 0.00009 & 0.18021 & 0.18377 & 0.16499 \\
\hline AR & 0.16609 & 0.00000 & 0.17770 & 0.00000 & 0.17296 & 0.16852 & 0.17447 \\
\hline
\end{tabular}




\section{References}

1. Commission of the European Communities. Green Paper. A European Strategy for Sustainable, Competitive and Secure Energy; SEC(2006)317. Available online: https:/ / eur-lex.europa.eu/legal-content/EN/TXT/PDF/?uri=CELEX:52006DC0105\&from=PL (accessed on 11 November 2020).

2. International Energy Agency. Available online: www.iea.org/data-and-statistics (accessed on 18 December 2020).

3. Jelonek, D.; Stępniak, C.; Turek, T.; Ziora, L. Planning Cities Development Directions with the Application of Sentiment Analysis. Prague Econ. Pap. 2020, 3, 274-290. [CrossRef]

4. Jelonek, D.; Stepniak, C.; Turek, T. The concept of building regional business spatial community. In Proceedings of the 2013 International Conference on e-Business (ICE-B), Reykjavik, Iceland, 29-31 July 2013; pp. 1-8.

5. Falcone, P.M. Analysing stakeholders' perspectives towards a socio-technical change: The energy transition journey in Gela Municipality. AIMS Energy 2018, 6, 645-657. [CrossRef]

6. Koepke, M.; Monstadt, J.; Otsuki, K. Rethinking energy transitions in Southern cities: Urban and infrastructural heterogeneity in Dar es Salaam. Energy Res. Soc. Sci. 2021, 74, 101937. [CrossRef]

7. Pulselli, R.M.; Broersma, S.; Martin, C.L.; Keeffe, G.; Bastianoni, S.; Dobbelsteen, A.V.D. Future city visions. The energy transition towards carbon-neutrality: Lessons learned from the case of Roeselare, Belgium. Renew. Sustain. Energy Rev. 2021, 137, 110612. [CrossRef]

8. Mitchell, W.J. Intelligent cities. e-J. Knowl. Soc. 2007, 5, 4-9. Available online: https://uocpapers.uoc.edu/uocpapers/5/dt/eng/ mitchell.html (accessed on 10 January 2021).

9. Komninos, N. The Age of Intelligent Cities. Smart Environments and Innovation-for-All Strategies; Routledge: New York, NY, USA, 2015.

10. Yeh, H. The effects of successful ICT-based smart city services: From citizens' perspectives. Gov. Inf. Q. 2017, 34, 556-565. [CrossRef]

11. Kourtit, K.; Nijkamp, P. Smart cities in the innovation age. Innov. Eur. J. Soc. Sci. Res. 2012, 25, 93-95. [CrossRef]

12. Yigitcanlar, T. Smart cities: An effective urban development and management model? Aust. Plan. 2015, 52, 27-34. [CrossRef]

13. Giourka, P.; Sanders, M.W.; Angelakoglou, K.; Pramangioulis, D.; Nikolopoulos, N.; Rakopoulos, D.; Tzovaras, D. The smart city business model canvas-A smart city business modeling framework and practical tool. Energies 2019, 12, 4798. [CrossRef]

14. Sobczak, A. Model of delivering value from the construction of a smart city. Ann. Coll. Econ. Anal. 2014, 33, 487-496.

15. Guedes, A.L.A.; Alvarenga, J.C.; Goulart, M.D.S.S.; Rodriguez, M.V.R.Y.; Soares, C.A.P. Smart Cities: The Main Drivers for Increasing the Intelligence of Cities. Sustainability 2018, 10, 3121. [CrossRef]

16. Veselitskaya, N.; Karasev, O.; Beloshitskiy, A. Drivers and barriers for smart cities development. Theor. Empir. Res. Urban Manag. 2019, 14, 85-110.

17. Nicula, A.-S.; Boțan, C.N.; Gligor, V.; Cociș, E.-A. Celebrating the Great Union through Smart Digital Solutions: Lessons from Alba Iulia, Romania. J. Urban Hist. 2020. [CrossRef]

18. Creţan, R.; Málovics, G.; Méreiné-Berki, B. On the perpetuation and contestation of racial stigma: Urban Roma in a disadvantaged neighbourhood of Szeged. Geogr. Pannonica 2020, 24, 294-310. [CrossRef]

19. Satyam, A.; Calzada, I. The Smart City Transformations: The Revolution of the 21st Century; Bloomsbury Publishing: London, UK, 2017.

20. Creţan, R.; O'Brien, T. Corruption and conflagration: (in)justice and protest in Bucharest after the Colectiv fire. Urban Geogr. 2020, 41, 368-388. [CrossRef]

21. Jaššo, M.; Petríková, D. Towards creating place attachment and social communities in the SMART cities. In Smart Technology Trends in Industrial and Business Management; Springer: Cham, Switzerland, 2019; pp. 401-411.

22. Bonetto, R.; Rossi, M. Smart Gird for the Smart City. In Designing, Developing, and Facilitating Smart Cities; Angelakis, V., Tragos., E., Pöhls, H., Kapovitas, A., Bassi, A., Eds.; Springer: Cham, Switzerland, 2017; pp. 241-263. [CrossRef]

23. Tsolakis, N.; Anthopoulos, L. Eco-cities: An integrated system dynamics framework and a concise research taxonomy. Sustain. Cities Soc. 2015, 17, 1-14. [CrossRef]

24. Steemers, K. Energy and the city: Density, buildings and transport. Energy Build. 2003, 35, 3-14. [CrossRef]

25. Hu, J.-L.; Wang, S.-C. Total-factor energy efficiency of regions in China. Energy Policy 2006, 34, 3206-3217. [CrossRef]

26. Honma, S.; Hu, J.-L. Total-factor energy efficiency of regions in Japan. Energy Policy 2008, 36, 821-833. [CrossRef]

27. Cherubini, F.; Bargigli, S.; Ulgiati, S. Life cycle assessment of urban waste management: Energy performances and environmental impacts. The case of Rome, Italy. Waste Manag. 2008, 28, 2552-2564. [CrossRef]

28. Kozhevnikov, S.; Skobelev, P.; Pribyl, O.; Svitek, M. Development of Resource-Demand Networks for Smart Cities 5.0. In Industrial Applications of Holonic and Multi-Agent Systems; (HoloMAS, 2019, Lecture Notes in Computer Science); Marik, V., Kadera, P., Rzevski, G., Zoitl, A., Anderst-Kotsis, G., Tjoa, A.M., Khalil, I., Eds.; Springer: Cham, Switzerland, 2019; Volume 11710, pp. 203-217. [CrossRef]

29. Haarstad, H.; Wathne, M.W. Are smart city projects catalyzing urban energy sustainability? Energy Policy 2019, 129, 918-925. [CrossRef]

30. Gargiulo, C.; Russo, L. Cities and Energy Consumption: Strategies for an Energy Saving Planning. In Smart Planning: Sustainability and Mobility in the Age of Change. Green Energy and Technology; Papa, R., Fistola, R., Gargiulo, C., Eds.; Springer: Cham, Switzerland, 2018; pp. 49-70. [CrossRef] 
31. Anthopoulos, L.G. The Smart City in Practice. In Understanding Smart Cities: A Tool for Smart Government or an Industrial Trick? (Public Administration and Information Technology); Springer: Cham, Switzerland, 2017; Volume 22, pp. 215-262. [CrossRef]

32. Trianni, A.; Merigó, J.M.; Bertoldi, P. Ten years of Energy Efficiency: A bibliometric analysis. Energy Effic. 2018, 11, 1917-1939. [CrossRef]

33. Porro, O.; Pardo-Bosch, F.; Agell, N.; Sanchez, M. Understanding location decisions of energy multinational enterprises within the European smart cities' context: An integrated AHP and extended fuzzy linguistic TOPSIS method. Energies 2020, $13,2415$. [CrossRef]

34. Colapinto, C.; Jayaraman, R.; Ben Abdelaziz, F.; La Torre, D. Environmental sustainability and multifaceted development: Multi-criteria decision models with applications. Ann. Oper. Res. 2020, 293, 405-432. [CrossRef]

35. D'Adamo, I.; Falcone, P.M.; Gastaldi, M.; Morone, P. RES-T trajectories and an integrated SWOT-AHP analysis for biomethane. Policy implications to support a green revolution in European transport. Energy Policy 2020, 138, 111220. [CrossRef]

36. Jayaraman, R.; Colapinto, C.; La Torre, D.; Malik, T. Multi-criteria model for sustainable development using goal programming applied to the United Arab Emirates. Energy Policy 2015, 87, 447-454. [CrossRef]

37. Dell'Ovo, M.; Dell'Anna, F.; Simonelli, R.; Sdino, L. Enhancing the Cultural Heritage through Adaptive Reuse. A Multicriteria Approach to Evaluate the Castello Visconteo in Cusago (Italy). Sustainability 2021, 13, 4440. [CrossRef]

38. Estévez, R.A.; Espinoza, V.; Ponce Oliva, R.D.; Vásquez-Lavín, F.; Gelcich, S. Multi-Criteria Decision Analysis for Renewable Energies: Research Trends, Gaps and the Challenge of Improving Participation. Sustainability 2021, 13, 3515. [CrossRef]

39. Mardani, A.; Zavadskas, E.K.; Khalifah, Z.; Zakuan, N.; Jusoh, A.; Nor, K.M.; Khoshnoudi, M. A review of multi-criteria decision-making applications to solve energy management problems: Two decades from 1995 to 2015. Renew. Sustain. Energy Rev. 2017, 71, 216-256. [CrossRef]

40. Xu, T.; You, J.; Li, H.; Shao, L. Energy Efficiency Evaluation Based on Data Envelopment Analysis: A Literature Review. Energies 2020, 13, 3548. [CrossRef]

41. Geng, Y.; Zhang, H. Coordination assessment of environment and urbanization: Hunan case. Environ. Monit. Assess. 2020, 192, 637. [CrossRef]

42. Fang, C.; Pang, B.; Liu, H. Quantitative Study on the Dynamic Mechanism of Smart Low-Carbon City Development in China Sustainability 2016, 8, 507. [CrossRef]

43. Pang, B.; Fang, C. TOPSIS-based measurement and analysis on dynamics of smart low-carbon development for major Chinese cities. J. Landsc. Res. 2016, 8, 51-58, 62. [CrossRef]

44. Luo, J.; Chen, S.; Sun, X.; Zhu, Y.; Zeng, J.; Chen, G. Analysis of city centrality based on entropy weight TOPSIS and population mobility: A case study of cities in the Yangtze River Economic Belt. J. Geogr. Sci. 2020, 30, 515-534. [CrossRef]

45. Zhu, S.; Li, D.; Feng, H. Is smart city resilient? Evidence from China. Sustain. Cities Soc. 2019, 50, 101636. [CrossRef]

46. Ozkaya, G.; Erdin, C. Evaluation of smart and sustainable cities through a hybrid MCDM approach based on ANP and TOPSIS technique. Heliyon 2020, 6, e05052. [CrossRef] [PubMed]

47. Stanković, J.; Džunić, M.; Džunić, Ž.; Marinković, S. A multi-criteria evaluation of the European cities' smart performance: Economic, social and environmental aspects. J. Econ. Bus. 2017, 35, 519-550. [CrossRef]

48. Carli, R.; Dotoli, M.; Pellegrino, R. Multi-criteria decision-making for sustainable metropolitan cities assessment. J. Environ. Manag. 2018, 226, 46-61. [CrossRef]

49. Li, J.; Gong, L.; Chen, Z.; Zeng, L.; Yang, G.; Zhang, J. The Hierarchy and Transition of China's Urban Energy Efficiency. Energy Procedia 2016, 104, 110-117. [CrossRef]

50. Wang, L.; Long, R.; Chen, H. Study of Urban Energy Performance Assessment and Its Influencing Factors Based on Improved Stochastic Frontier Analysis: A Case Study of Provincial Capitals in China. Sustainability 2017, 9, 1110. [CrossRef]

51. Wang, X.; Li, Z. A systematic approach to evaluate the impact of urban form on urban energy efficiency: A case study in Shanghai. Energy Procedia 2017, 105, 3225-3231. [CrossRef]

52. Li, Y.; Chiu, Y.-H.; Lu, L.C. Urban energy environment efficiency in China: Based on dynamic meta-frontier slack-based measures. J. Air Waste Manag. Assoc. 2019, 69, 320-332. [CrossRef] [PubMed]

53. Huang, H.; Chen, X.; Yue, X.; Chen, M. The Relationship between Industrial Production Performance and Energy Conservation Efficiency in Coastal and Inland Cities in China. J. Coast. Res. 2019, 96, 12-20. [CrossRef]

54. Dirutigliano, D.; Delmastro, C.; Moghadam, S.T. A multi-criteria application to select energy retrofit measures at the building and district scale. Therm. Sci. Eng. Prog. 2018, 6, 457-464. [CrossRef]

55. Lombardi, P.; Abastante, F.; Moghadam, S.T.; Toniolo, J. Multicriteria Spatial Decision Support Systems for Future Urban Energy Retrofitting Scenarios. Sustainability 2017, 9, 1252. [CrossRef]

56. Moutinho, V.; Madaleno, M.; Robaina, M.; Villar, J. Advanced scoring method of eco-efficiency in European cities. Environ. Sci. Pollut. Res. 2018, 25, 1637-1654. [CrossRef] [PubMed]

57. Song, T.; Cai, J.; Yang, Z.; Chen, M.; Lin, J. Urban metabolic efficiencies and elasticities of Chinese cities. Chin. Geogr. Sci. 2016, 26, 715-730. [CrossRef]

58. Liu, C.; Zhou, Z.; Liu, Q.; Xie, R.; Zeng, X. Can a low-carbon development path achieve win-win development: Evidence from China's low-carbon pilot policy. Mitig. Adapt. Strat. Glob. Chang. 2020, 25, 1199-1219. [CrossRef]

59. Wang, S.; Gao, S.; Huang, Y.; Shi, C. Spatiotemporal evolution of urban carbon emission performance in China and prediction of future trends. J. Geogr. Sci. 2020, 30, 757-774. [CrossRef] 
60. Wang, L.; Yuan, G.; Long, R.; Chen, H. An urban energy performance evaluation system and its computer implementation. J. Environ. Manag. 2017, 204, 684-694. [CrossRef]

61. Zheng, X.; Lianguang, M. Analysis of the factors influencing the area distribution of urban energy efficiency. In Proceedings of the 3rd International Conference on Intelligence System Design and Engineering Applications, Hong Kong, China, 16-18 January 2013. [CrossRef]

62. Su, M.; Li, R.; Lu, W.; Chen, C.; Chen, B.; Yang, Z. Evaluation of a Low-Carbon City: Method and Application. Entropy 2013, 15, 1171-1185. [CrossRef]

63. Chodakowska, E.; Nazarko, J. Assessing the Performance of Sustainable Development Goals of EU Countries: Hard and Soft Data Integration. Energies 2020, 13, 3439. [CrossRef]

64. Wang, L.; Long, R.; Chen, H.; Li, W.; Yang, J. A review of studies on urban energy performance evaluation. Environ. Sci. Pollut. Res. 2019, 26, 3243-3261. [CrossRef]

65. Hajduk, S. The Smartness Profile of Selected European Cities in Urban Management-A Comparison Analysis. J. Bus. Econ. Manag. 2018, 19, 797-812. [CrossRef]

66. Hajduk, S. Assessment of urban transport-A comparative analysis of selected cities by taxonomic methods. Eng. Manag. Prod. Serv. 2016, 8, 67. [CrossRef]

67. ISO37122. Sustainable Cities and Communities-Indicators for Smart Cities. Available online: https://www.iso.org/obp/ui/\#iso: std:iso:37122:ed-1:v1:en (accessed on 10 November 2020).

68. ISO37123. Sustainable Cities and Communities-Indicator for Resilient Cities. Available online: https://www.iso.org/obp/ui/ \#iso:std:iso:37123:ed-1:v1:en (accessed on 21 November 2020).

69. Fox, M.S. The role of ontologies in publishing and analyzing city indicators. Comput. Environ. Urban Syst. 2015, 54, 266-279. [CrossRef]

70. Hwang, C.L.; Yoon, K. Multiple Attributes Decision Making Methods and Application; Lecture Notes in Economics and Mathematical Systems; Springer: Berlin/Heidelberg, Germany, 1981. [CrossRef]

71. Halicka, K. Technology Selection Using the TOPSIS Method. Foresight STI Gov. 2020, 14, 85-96. [CrossRef]

72. Ban, A.J.; Ban, O.J.; Bogdan, V.; Sabau Popa, D.C.; Tuse, D. Performance evaluation model of Romanian manufacturing listed companies by fuzzy AHP and TOPSIS. Technol. Econ. Dev. Econ. 2020, 26, 808-836. [CrossRef]

73. Hajduk, S. Instruments of Spatial Management in the Context of Sustainability-A Multi-Dimensional Comparative Analysis of the Regional Cities. Annu. Set Environ. Prot. 2018, 20, 1219-1233.

74. Fox, M.S. The semantics of populations: A city indicator perspective. J. Web Semant. Sci. Serv. Agent World Wide Web 2018, 48, 48-65. [CrossRef]

75. World Council on City Data. Available online: http:/ / open.dataforcities.org/ (accessed on 9 November 2019). 